\title{
Henkistä pääomaa ja taloudellista hyötyä tilojen välisellä yhteistyöllä
}

\author{
Anu Raatikainen ${ }^{1,2)}$, Risto Kauppinen ${ }^{1)}$, Kati Partanen ${ }^{1)}$, Ossi Tuuliainen ${ }^{3)}$ \\ 1)Savonia-ammattikorkeakoulu,PL 72, 74101 Iisalmi, etunimi.sukunimi@savonia.fi \\ 2)MTK-Etelä-Savo, PL 31, 50101 Mikkeli, etunimi.sukunimi@mtk.fi \\ 3)Etelä-Savon ELY-keskus, PL 164, 50101 Mikkeli, etunimi.sukunimi@ely-keskus.fi
}

\section{Tiivistelmä}

Eteläsavolaisten tilojen keskimääräinen peltopinta-ala on n. 10 ha pienempi kuin muualla maassa. Pienien peltoalojen ja -lohkojen lisäksi tilusrakennetta heikentää myös runsas vesistöjen määrä. Heikkoon tilusrakenteeseen haetaan vastausta muilla kilpailukykytekijöillä kuten esim. tilojen välisellä yhteistyöllä ja verkostoitumisella. Etelä-Savossa selvitettiin syksyllä 2012 teemahaastattelun avulla maatilojen (9) palvelutarpeita sekä tilojen välistä yhteistyötä. Haastatelluissa tiloissa oli lypsykarjatiloja, naudanlihan tuotantotiloja sekä yksi monialainen tila. Teemakysymykset pohjautuivat Etelä-Savon maaseudun kehittämisen toimenpideohjelmassa esiin tulleisiin kehittämiskohteisiin.

Tutkimuksen aluksi asetettiin kolme hypoteesia: 1 . Maatilan yhteistyö lisääntyy tilakoon kasvaessa ja työn määrän lisääntyessä. 2. Tilan sijainti toisiin tiloihin nähden vaikuttaa yhteistyön määrään ja muotoihin. 3. Tilakoon ja työmäärän kasvaessa urakointipalveluja käytetään enemmän. Lisäksi haluttiin selvittää mitkä asiat kehittävät tilat kokevat tärkeimmiksi kilpailukykytekijöiksi.

Tilakoon kasvaessa tilojen välistä yhteistyötä tehdään ja sillä koetaan olevan sekä taloudellista että sosiaalista merkitystä. Tilakoko ja tilan muuttuvat tarpeet vaikuttavat toteutuvan yhteistyön muotoihin ja yhteistyökumppanin valintaan. Yhteistyön muodostumiseen ja uusien verkostojen luomiseen vaikuttavat mm. aikaisemmat kokemukset yhteistyöstä. Tilan sijainti suhteessa potentiaalisiin yhteistyökumppaneihin ei ole merkittävä tekijä yhteistyön syntymiselle. Enemmän kuin tilojen välinen keskinäinen etäisyys yhteistyön syntymiseen vaikuttivat tilan strategia, tarpeet sekä henkilökemiat. Lähekkäin sijaitsevat tilat eivät ole aina toimivin yhteistyöverkosto, vaikka se olisikin taloudellisesti edullisin vaihtoehto. Tilakoon kasvu ei välttämättä lisää urakointipalvelujen käyttöä. Tutkimukseen osallistuneet tilat halusivat pitää maidontuotannon perusprosessit, lypsyn ja säilörehun tuotannon, omassa hallinnassa, koska esim. säilörehun laatua pidettiin merkittävänä tekijänä tilan talouden kannalta.

Tilakoon kasvaessa joudutaan tekemään strateginen valinta ulkoistetaanko tuotantoprosessi vai kotiutetaanko prosesseja ja palkataan tilalle työvoimaa. Laajentavat tilat saattavat valita prosessien ulkoistamisen sijaan jopa mieluummin prosessien kotiuttamisen ja palkata vierasta työvoimaa. Urakointipalvelut nähtiin strategisena vaihtoehtona korvausinvestoinnin tekemiselle.

Tutkimukseen haastatellut tilat tunnistivat kilpailukykytekijöiksi mm. ammattitaidon, säilörehun hyvän laadun, koneyhteistyön sekä hyvän tilusrakenteen. Lisäksi kilpailukykytekijöiksi mainittiin kohtuullinen vieraan pääoman määrä, työtä helpottavat yksinkertaiset tuotantotekniikan ratkaisut, kustannusten karsiminen, tilan toiminnan ennakointi ja talouden hallinta. Maatilojen välinen yhteistyö ja verkostoituminen tuovat maatilalle paitsi taloudellisia hyötyjä, myös lisää henkistä pääomaa, osaamista ja kokemusta.

\section{Asiasanat}

maatalouden rakenne, yhteistyö, strategia 


\section{Johdanto}

Vuonna 2011 Suomessa oli 61584 maatilaa, joista yli hehtaarin kokoisia tukea hakeneita tiloja oli 61 $200 \mathrm{kpl}$. Tilojen määrä väheni reilulla tuhannella vuoteen 2010 verrattuna. Suomalaisten maatilojen keskipeltoala vuonna 2011 oli n. 37 ha. Lypsykarjatiloja oli 10597 lypsykarjatilaa ja niiden keskipeltopinta-ala oli 52,80 ha. Muuta nautakarjataloutta harjoitettiin 3820 tilalla, joiden keskipeltopinta-ala oli 53,66 hehtaaria. (SVT: Tike, Maatilojen rakenne 2012)

Koko maan tilojen keskipeltoala kasvoi aikavälillä 2000 - 2010 vuoden aikana n. 9 ha; samaan aikaan tilojen määrä on vähentynyt. (SVT: Tike, Maatilojen rakenne 2012) Suomalaisten tilojen koko kasvaa edelleen. Vuonna 2010 jo yli kolmannes oli yli 75 ha tilojen hallinnassa ja lähes $60 \%$ Suomen peltopinta-alasta oli yli 50 ha:n tilojen hallinnassa.

Vuonna 2011 Etelä-Savon maakunnassa oli 2963 maatilaa, mikä oli 4,8 \% koko valtakunnan tilamäärästä. (MTT, 2012, 14) Vuonna 2011 Etelä-Savon ELY-keskusalueella oli 644 maitotilaa, joiden hallinnassa oli yhteensä 26288 ha peltoa. Maitotilojen keskimääräinen peltopinta-ala on n. 41,01 ha / tila, mikä on n. kymmenen hehtaaria pienempi kuin koko maan maitotilojen keskipeltopinta-ala. (SVT: Tike, Maatilojen rakenne 2012)

Pienten peltoalojen ja -lohkojen lisäksi tilusrakenteeseen vaikuttaa heikentävästi myös runsas vesistöjen määrä. Heikkoon tilusrakenteeseen haetaan vastausta muilla kilpailukykytekijöillä kuten esim. tilojen välisellä yhteistyöllä ja verkostoitumisella.

\section{Aineisto ja menetelmät}

Etelä-Savossa selvitettiin syksyllä 2012 teemahaastattelun avulla maatilojen (9 kpl) palvelutarpeita ja tilojen välistä yhteistyötä. Työn teoreettisessa viitekehyksessä kuvataan tilastotietojen perusteella maatalouden nykyistä tilannetta Suomessa ja Etelä-Savon alueella. Lisäksi verrataan Suomen maatilojen rakennetta vuonna 2010 Tanskan tilarakenteeseen vuonna 1990 ja Ruotsin tilarakenteeseen vuonna 1995.

Työn tutkimusosassa pyrittiin teemahaastattelututkimuksen avulla selvittämään laajentavilta sekä toimintaansa kehittävien maatilojen kokemuksia verkostoitumisesta, koneyhteistyöstä, ulkoistamisesta sekä ulkopuolisen työvoiman käytöstä. Haastatelluissa tiloissa oli lypsykarjatiloja, naudanlihan tuotantotiloja sekä yksi monialainen tila. Teemahaastattelun kysymykset pohjautuivat Etelä-Savon maaseudun kehittämisen toimenpideohjelmassa esiin tulleisiin kehittämiskohteisiin.

Tutkimuksen aluksi asetettiin kolme hypoteesia: 1. Maatilan yhteistyö lisääntyy tilakoon kasvaessa ja työn määrän lisääntyessä. 2. Tilan sijainti toisiin tiloihin nähden vaikuttaa yhteistyön määrään ja muotoihin. 3. Tilakoon ja työmäärän kasvaessa urakointipalveluja käytetään enemmän. Lisäksi haluttiin selvittää mitä asioita kehittävät tilat kokevat tärkeimmiksi kilpailukykytekijöiksi.

Haastattelut tehtiin teemahaastatteluna viiden eri kunnan alueella sijaitseville tiloille. Vastaukset tallennettiin PC:lle äänitiedostoksi, litteroitiin sekä analysoitiin. Aineiston analysointitapa on lähinnä kvalitatiivinen sisällönanalyysi, jossa mm. tutustutaan aineistoon, sisäistetään aineisto, luokitellaan se karkeasti, täsmennetään tehtävää, luokitellaan uudelleen sekä tehdään johtopäätöksiä ja tulkinnat (Metsämuuronen, 2006, 244). Raportissa on kuitenkin pyritty vähintään käsitteellistämään havainnot sekä tarkentamaan tutkimustehtävää tutkimuksen kuluessa (Metsämuuronen, 2006, 252). Esim. tilojen ennakointiin liittyvä kysymys oli hetkelliseen intuitioon perustuva.

\section{Tulokset ja tulosten tarkastelu}

Haastateltujen tilojen vastausten perusteella tilojen välistä yhteistyötä tehdään, sekä horisontaalisissa että vertikaalisissa verkostoissa ja yhteistyöllä koetaan olevan sekä taloudellista, että sosiaalista merkitystä. Tilakoko ja tilan muuttuvat tarpeet vaikuttavat yhteistyön muotoihin ja yhteistyökumppaneiden valintaan. Yhteistyön muodostumiseen ja uusien verkostojen luomiseen vaikuttavat mm. aikaisemmat kokemukset yhteistyöstä.

Ensimmäisenä hypoteesina oli, että tilakoon kasvu ja työn määrän lisääntyminen lisäisi myös yhteistyötä. Näin ei välttämättä ole. Tilakoon kasvu ei automaattisesti tarkoita yhteistyön lisääntymistä. Tilakoon kasvu vaikuttaa koneiden yhteisomistuksiin mutta ei välttämättä lisää sitä. Tilakoon kasvaessa potentiaalinen yhteistyöyritysten joukko pienenee. Tilakokojen kasvaessa yhteiskoneiden kapasiteetti voi jäädä pieneksi, jos kaikki yhteiskoneen omistava tilat laajentavat toimintaa. Konekapasiteetin pienuus voi tulla tällöin eteen varsin nopeastikin esim. haasteellisten sääolosuhteiden vuoksi. Yhteistyökuvioita voidaan joutua myös purkamaan tilakoon muuttuessa ja tilojen tarpeiden muuttuessa. 
Yhteistyön ja verkostoitumisen lisääntymiseen vaikuttivat muut tekijät kuin tilakoon kasvu tai työn määrän lisääntyminen. Esim. tilan omat aikaisemmilla kokemuksilla yhteistyöstä on merkitystä. Onnistuneet kokemukset esim. koneiden yhteisomistuksesta kannustivat hankkimaan uusia yhteiskoneita. Osaaminen ja kokemus, eli henkinen pääoma, yhteisen koneen hankintaan oli jo olemassa. Yhteisomistajuus syntyy luontevasti ja sen kestävyyden mahdollistaa se, että tilat pitävät kiinni omasta tavastaan toimia.

Toisena hypoteesina oli ajatus siitä, että tilojen sijainti suhteessa toisiin yhteistyötiloihin vaikuttaisi tilojen välisen yhteistyön määrään. Sekään ei välttämättä pidä paikkaansa. Enemmän kuin tilojen välinen keskinäinen etäisyys, yhteistyön syntymiseen vaikuttivat tilan strategia, tarpeet sekä henkilökemiat. Lähekkäin toimivat tilat eivät aina ole toimivin yhteistyöverkosto vaikka se olisikin taloudellisesti edullisin vaihtoehto.

Kolmas hypoteesi oli, että tilakoon kasvu lisäisi urakointipalveluiden määrää. Tämäkään hypoteesi ei aina pidä paikkaansa. Tilakoon kasvaessa joudutaan tekemään strategisia valintoja vaihtoehtojen: yhteistyö, tuotantoprosessin ulkoistaminen, tuotantoprosessin kotiuttaminen ja ulkopuolisen työvoiman palkkaaminen välillä. Jos sopivan urakoitsijan löytäminen on hankalaa, laajentavat tilat saattavat valita prosessien ulkoistamisen sijaan prosessien kotiuttamisen ja palkata tilalle työvoimaa. Vaihtoehtoinen strategia on myös kotiuttaa jokin prosessi, palkata ulkopuolista työvoimaa ja tarjota itse kyseistä palvelua. Sopivan palvelun tarjoajan puute oli myös esteenä urakointipalvelujen käytölle; erityisesti tämä tuli esiin kasvinsuojeluruiskutusten osalta. Myös yrityksen elinkaari vaikuttaa urakointipalvelujen käyttöön, sillä ns. jäähdyttelevät tilat tai toimintansa vakiinnuttaneet tilat voivat valita ulkoistamisen vaihtoehdoksi korvausinvestoinneille.

Haastattelussa tutkittiin myös, mitä asioita tilat pitivät omien tilojensa kilpailukykytekijöinä. Tilat tunnistivat kilpailukykytekijöikseen mm. ammattitaidon, koneyhteistyön, säilörehun hyvän laadun, sekä hyvän tilusrakenteen. Kilpailukykytekijöiksi mainittiin myös kohtuullinen vieraan pääoman määrä, työtä helpottavat yksinkertaiset tuotantotekniikan ratkaisut, kustannusten karsiminen, tilan toiminnan ennakointi ja tilan talouden seuranta ja hallinta.

Kilpailukykytekijöistä säilörehun laatu nousi yllättävän merkittävään asemaan ja sitä pidettiin tilojen tuotannon ja tuotantotalouden kannalta niin merkittävänä osaprosessina, että se haluttiin pitää omassa hallinnassa ja mieluummin palkattiin ulkopuolista työvoimaa lypsytyöhön ja karjanhoitoon. Myös tilusrakenne, jossa pellot sijaitsevat lähellä tuotantorakennuksia vaikuttaa tilan energia- ja panostehokkuuteen. Tulevaisuudessa energian hinnan noustessa peltojen ja tilakeskuksen etäisyyden merkitys korostuu.

Teemahaastattelussa nousi esiin ajoittaisen työvoiman tarve kaikkien tuotantosuuntien tiloilla. Kaksi tiloista oli palkannut ulkopuolista työvoimaa ja muilla tiloilla oli ollut ajatuksia yhteisen työntekijän palkkaamisesta.

Työvoiman palkkaamiseen on tarvetta myös pienemmillä tiloilla, mutta palkkakustannukset voivat muodostua pienemmille tiloille kynnyskysymykseksi. Työntekijän palkkaamisen esteenä pidettiin myös sitä, että pienemmät tilat eivät yksin pysty työllistämään työntekijää kokoaikaisesti sekä sitä, että työntekijän palkkaaminen ja työhön perehdyttäminen on prosessi, johon kaikilla tiloilla ei riitä taloudellista tai aikaresurssia. Asiassa etenemiseen voidaan tarvita ulkopuolista apua.

Toinen tutkimustulosten perusteella esiin nouseva kokonaisuus liittyy tilojen johtamiseen. Esiin nousivat erityisesti johtamistyön tuottavuuden merkitys sekä strategisten valintojen merkitys tiloille. Tutkimuksen perusteella tilojen johtamisosaamisessa strategisen ja tavoitteellisen johtamisen merkitys korostuu. Strategisten päätösten teko tiloilla on tulevaisuudessa entistä tärkeämpää, sillä tilakokojen kasvaessa myös tehtävien päätösten ja valintojen merkitys kasvaa. Ne tilat, jotka laajentavat esim. robottitiloilla tekevät tulevaisuudessa isompia laajennuksia kerralla joten tämän hetkisellä tuotantoteknologian valinnalla vaikutetaan myös tuleviin valintoihin. Strategisiin valintoihin on hyvä liittää jonkinlainen esim. hankinnan elinkaariajattelu, koska rakennemuutoksessa mikään ratkaisu ei voi olla pysyvä. Pitää osata myös luopua pieneksi ja tarpeettomaksi käyneestä. Toimintaympäristön muuttuessa on päätettävä milloin ja mihin reagoidaan. Reagointi on aina sen tehtävä, joka tilaa johtaa.

Riippumatta siitä, kuka tilan työt tekee, kaikki strategiset vaihtoehdot: tilojen välinen yhteistyö, ulkoistaminen ja ulkopuolisen työvoiman käyttö lisäävät johtamistyön määrää. Johtamistyön tuottavuutta olisi hyvä pystyä mittamaan ja havainnollistamaan, jolloin pystytään lisäämään johtamistyön tuottavuutta. 
Työn tuottavuutta voidaan lisätä myös osaamisella (Teknologiateollisuus, 2006, 26 ). Kestin mukaan $(2007,13)$ tuottavuudeltaan paremmilla yrityksillä on usein samat lähtökohdat kuin keskivertoyrityksilläkin. Tuottavammat organisaatiot eroavat keskivertoyrityksistä siinä, että niillä on kyky jalostaa aineetonta pääomaa esim. innovaatioita toimintatavoiksi. Karlöfin ym. $(2003,34)$ mukaan henkinen pääoma on aineetonta pääomaa ja silla tarkoitetaan yleensä kykyä hallita koodattua tai hiljaista tietoa.

Kestin $(2007,20)$ mukaan tuottavuudeltaan paremmissa yrityksissä kyetään kehittämään uusia työmenetelmiä tai liiketoimintaratkaisuja. Em. kehittäminen vaatii pitkäjänteisyyttä sekä jatkuvuutta. Huipputuottavat organisaatiot eroavat keskivertoyrityksistä siinä, että ne turvaavat hyvän kehityksen jatkumisen, kun tavoite on saavutettu. Tuottavassa organisaatiossa ei lopeteta toiminnan kehittämistä, kun saavutetaan hyviä tuloksia vaan toiminnan kehittämistä jatketaan.

Karlöfin ym. $(2003,44)$ mukaan yrityksen menestymisen kannalta tiedonmuodostus ja hallinta ovat erittäin tärkeitä. Yritysten ongelma on usein kuitenkin siinä, että tiedonhallinta painottuu usein informaation kokoamiseen ja tallentamiseen mutta sitä ei saada muutettua tiedoksi. Tietoa kotaan mutta sitä ei kyetä jalostamaan vastaanottajapuolen tarvitsemaksi tiedoksi. Vasta oikeaa informaatiota tiedoksi jalostamalla muodostuu osaamista.

Johtamistyön ja -osaamisen merkitys näkyy erityisesti tilan toiminnan ennakoinnissa sekä hankinnoissa. Ennakoinnilla on taloudellista merkitystä, koska sen avulla voidaan ehkäistä toiminnallisia riskejä ja välttää toimintaa haittaavia virheitä. Ajatustyöllä ja suunnittelulla voidaan käytännön työssä säästää vuoden aikana lukuisia euroja. Johtamistyön merkitys korostuu myös siinä, että tilan osaprosesseista saadaan muodostumaan toimiva kokonaisuus. Tuottavuutta lisätään työn ja tuotteiden laadulla ja myös sillä, että siirtymät prosessista toiseen tapahtuvat sujuvasti. Tilan toiminnassa, minkä tahansa työn, esim. rehun siirto ruokintaan, päivittäisessä suorittamisessa saatava 10 minuutin ajansäästö merkitsee 60 tunnin ajansäästöä vuodessa.

Johtamistyön tuottavuuden edistämiseen liittyy myös tilojen tietoisuuden lisääminen siitä, että henkisellä pääomalla ja osaamisella on merkitystä tuottavuuden tekijänä. Minkälainen ja -kokoinen tila tahansa voi kehittää toimintaansa ja toimintatapojaan tavoitteellisesti ja saada siitä euroissa mitattavaa hyötyä.

Tilojen johtamisosaamisen kannalta merkittävää on oman tilan tiedonhallinta, jossa yhdistyvät tilastotiedot sekä tilojen oma hiljainen tieto ja kokemus niistä asioista, esim. käytännön työmenetelmistä ja tilojen omista ratkaisuista ja työmenetelmien parannuksista, jotka eivät tilastoissa näy.

\section{Johtopäätökset}

Tutkimuksessa selvitettiin maatilojen kokemuksia tilojen välisestä yhteistyöstä, urakoinnista sekä ulkopuolisen työvoiman käytöstä. Asetetut hypoteesit maatilan yhteistyön ja urakointipalvelujen käytön lisääntymisestä tilakoon kasvaessa sekä tilojen sijainnin vaikutuksesta yhteistyön määrään eivät tulosten mukaan pidä paikkaansa, vaan tila valitsee strategiansa aina olosuhteiden, kokemusten ja koettujen kilpailukykytekijöiden mukaan. Esimerkiksi säilörehun laatu nähtiin niin merkittäväksi kilpailukykytekijäksi, että sen ulkoistaminen koettiin riskiksi.

Työvoiman tarve ja johtamisosaamisen lisääminen nousivat haastatteluissa voimakkaasti esiin kehittämiskohteina. Yrityksen johtamisen kehittämisessä kannattaa tarkastella tilan omia kilpailukykytekijöitä. Ne ovat tilan vahvuuksia ja on syytä pohtia, miten niitä voi vahvistaa tai hyödyntää enemmän. Verkostoituminen ja sosiaalinen kanssakäyminen lisäävät henkisen pääoman määrää, sillä hyvin verkostoituneella yrittäjällä on yleensä käytössään myös yhteistyökumppaneilta saatua ja opittua tietoa.

\section{Kirjallisuus}

Karlöf, B., Lundgren, K. \& Edenfeldt Froment, M. 2003. Ota oppia parhaista! Tehoa vertailuoppimisesta. Talentum. Jyväskylä: Gummerus Oy

Kesti, M. 2007. Huipputuottava organisaatio. Helsinki: Edita.

Metsämuuronen, J. 2006. Tutkimuksen tekemisen perusteet ihmistieteissä.

International Methelp. Jyväskylä: Gummerus Kirjapaino Oy

Niemi J.\& Ahlstedt J. (toim.). 2012. MTT Taloustutkimus. Suomen maatalous ja maaseutuelinkeinot 2012. Vammalan kirjapaino Oy 
SVT: Tike, Maatilojen rakenne 2012. Suomen virallinen tilasto (SVT) 2012: Maatilojen rakenne [verkkojulkaisu] Helsinki: Maa- ja metsätalousministeriön tietopalvelu-keskus, Tike [viitattu:

7.12.2012] ja [viitattu: 2.12.2012] Saatavissa: http://www.stat.fi/til/matira/index.html

Teknologiateollisuus ry \& Metalliliitto. 2006. Tuottavuuden tienviitat - Älyä peliin -julkaisu. Taitto Public Design Oy, Painopaikka KM-Yhtymä Oy. Saatavilla: http://www.metalliliitto.fi/ajankohtaista 